\title{
Developing attitude, love and value of art Education at the Secondary Stage
}

\section{Huidrom Rakesh Singh}

Research Scholar, Dept. Of Dance \& Music, Manipur University, Manipur, India

Email: rakesh huidrom@ymail.com

Abstract - The aim of this paper is to show about the development of feelings, respect, discipline, honest are the essential requirement of all round personality development for learner through art education at secondary stage.

Keywords-Cognitive, Affective, Psychomotor, Attitude, Love, Value.

\section{INTRODUCTION}

Art is all about developing a sense of beauty or study of aesthetic sense in normal teaching learning process, the 3 domain are kept at top priority they are

1) Cognitive domain: Thinking ability skills.

2) Affective domain: The feelings, attitude, emotion and value.

3) Psychomotor domain: The development of skill use of hand.

The three dimension of art education for achieving all round personality developed the learner are love, attitude and values.

The present education system demands for a system where children need to develop and grow both physically and mentally at the fullest. According to Mahatma Gandhi, "education all about bringing out of best from individual mind, soul and body".

The sole aim of including the art education in national curriculum is to develop the learner love, attitude and value toward things, others, environment and nature.

The UNESCO at the same time lays down 10 life skills for the children and adolescent. The life skills aim at enhancing the certain skill based on love, attitude and value. For any society to grow and develop positively these three core area of love, attitude and value is very essential.

LOVE: Love is one of the human beings feeling, affection and emotion. Love could be negative and positive. Through art education one can express his/her love painting, poem, song, video, films etc. It can also help the children to love each other and not to hurt others. These feeling will help in building a good society. At the same time will enhance in overall development of the learner. The ability of art to inspire from many perspectives draw and emotion, not merely out life through our involvement with its certain and by energizing our spirit beyond this involvement. The existence of uncommonly valuable human beings such as excellent artist increase our love of life.

ATTITUDE: Attitude means how a child sees and understand an object. Attitude is the very focal point of the respect and value. It is also another feeling in human being that developed gradually with the maturity level. The attitude towards other is very important because without this one cannot grow and develop. These can be again positive and negative. The teachers should help the children in converting the negative attitude towards a positive attitude while appreciating any form of art such as attitude is taken care.

VALUE: The teaching of art education emphasis on the value based learning, Value means the important of a thing. The children should have value for him, parents, teachers and his like and dislike too. The judging and valuing the art is very important in art education. Because the performer improve by the comment and observation made by viewer. Valuing the feedback and appreciation of the art is the very core of art education.

\section{CONCLUSION}

The 3 dimension of art education overlapped with the $2^{\text {nd }}$ domain of learning i.e affective domain. The domain indicates about the development of feelings. Respect, discipline, and honest are the essential requirement of all round personality development for learner. But this can be achieved when we inculcate the feeling if love, attitude and value in school system. The National Curriculum Framework 2005 in the present system of continuous and comprehensive. Evaluation (CCE) gives emphasis developing and enhancing these 3 dimensions. In the CCE, these areas of love, attitude and value are evaluated point in 
the co-scholastic manner. Because many educationist and thinker believe that these three dimensions help the children and learner to grow and develop fully without any fear. These help them to think positively and have positive outlook in life.

\section{REFERENCES}

[1] Aggarwal J.C. (2005), Teacher Education Theory and Practice, Doaba House 1688, Nai Sarak, Delhi-110006

[2] Blanche Jefferson (1963), Teaching Art to Children, United States of America

[3] Devi Prasad (1998), Art: The Basis of Education. National Book Trust, New Delhi.

[4] Manfred L. Keiler, (1955), art in the Schoolroom, University of Nebraska Press.

[5] Passi \& Singh, (2005), Value Education, National Psychological Corporation, 4/230, Kacheri Ghat, Agra-282 004

[6] Santidev Ghosh (1978), Music and Dance in Rabindranath Tagore's Education Philosophy, sangeet Natak Academi, New Delhi. 